\title{
Synthesis and Conformational Studies on [3.3.3]Metacyclophane Oligoketone Derivatives, and Their Metal Ion Recognition
}

\author{
Louis Korbla Doamekpor ${ }^{1}$, Raphael Kwaku Klake ${ }^{1}$, Vincent Kodzo Nartey ${ }^{1}$, \\ Takehiko Yamato², Oti Gyamfi ${ }^{3}$, Dennis Adotey ${ }^{3}$ \\ ${ }^{1}$ Department of Chemistry, University of Ghana, Accra, Ghana \\ ${ }^{2}$ Department of Chemistry, Saga University, Saga, Japan \\ ${ }^{3}$ Ghana Atomic Energy Commission, Accra, Ghana \\ Email: Ikdoamekpor@gmail.com
}

Received 21 March 2014; accepted 27 June 2015; published 30 June 2015

Copyright (C) 2015 by authors and Scientific Research Publishing Inc.

This work is licensed under the Creative Commons Attribution International License (CC BY). http://creativecommons.org/licenses/by/4.0/

\section{(c) (i) Open Access}

\begin{abstract}
Chemical reactions were used to synthesize 2,11,20-tris(ethanedithia)-9,18,27-trimethoxy-6,15, 24-tri-tert-butyl[3.3.3]metacyclophane 2 and 2,11-bis(ethanedithia)-9,18,27-trimethoxy-6,15,24tri-tert-butyl[3.3.3]metacyclophane 4 from 6,15,24-tri-tert-butyl-9,18,27-trimethoxy[3.3.3]metacyclophane-2,11,20-trione 1 and -2,11-dione 3. The yields of 2 and 4 were $70 \%$ and $81 \%$ respectively. The conformations of the synthesized compounds 2 and 4 were studied using mainly solution Proton Nuclear Magnetic Resonance ( ${ }^{1} \mathrm{H}$ NMR) spectroscopic methods. Compounds 2 and 4 were found to have a partial-cone conformation. Detailed variable temperature Proton Nuclear Magnetic Resonance studies further confirmed the partial-cone conformation for the two products, 2,4 . During the variable temperature nuclear magnetic resonance spectroscopic studies, compound 2 was found to have a coalescence temperature of about $0^{\circ} \mathrm{C}$. Extraction of silver ions with compound 2 gave an extractability of $82 \%$ while the parent compound 1 showed zero (0) silver affinity. A 1:1 mol/mol mixture of compound 2 and silver ions studied by solution ${ }^{1} \mathrm{H}$ NMR revealed a novel "Molecular Roulette" type of motion.
\end{abstract}

\section{Keywords}

Metacyclophanes, Macrocyclic Compounds, Cone, Partial-Cone, Conformation, Variable Temperature Proton Nuclear Magnetic Resonance Spectroscopy, Coalescence Temperature

\section{Introduction}

For several decades various research groups have been attracted to the chemistry and spectral properties of the

How to cite this paper: Doamekpor, L.K., Klake, R.K., Nartey, V.K., Yamato, T., Gyamfi, O. and Adotey, D. (2015) Synthesis and Conformational Studies on [3.3.3]Metacyclophane Oligoketone Derivatives, and Their Metal Ion Recognition. International Journal of Organic Chemistry, 5, 126-135. http://dx.doi.org/10.4236/ijoc.2015.52014 
metacyclophanes [1] [2]. Some of the studies bother on synthesis and conformational studies of the macrocyclic compounds in which researchers try to convert the flexible conformations of the synthesized macrocyclic compounds into rigid structures to serve as suitable platforms for various complexation experiments. Notable among the methods employed in constructing the rigid structures are those that deal with the introduction of various functional groups into the upper and lower rims, Figure 1, of the cyclic structures [3]. This method of preparing very stable units for host-guest studies places the functional groups on the aromatic units within the cyclic structure [4]-[7]. Other ways of freezing the various conformers include the introduction of the functional groups into the aliphatic units linking the various aromatic groups. This approach has been employed in studies involving cyclophanes with aromatic rings linked through $-\mathrm{CH}_{2} \mathrm{COCH}_{2}$ - bridges [8] [9]. These bridges are of special interest because of the ease with which carbonyl groups can be converted into other functional groups. For example, the conversion of the carbonyl groups into dithio groups yields hosts with sulfur atoms which can serve as further binding units for molecular recognition studies. The sulfur atoms together with the benzene rings tend to serve as sources of electrons needed to bind guests in the form of metal ions.

Cyclophane compounds bearing sulfur atoms [8] [9] have been known as intermediates in the preparation of various cyclophanes, particularly the paracyclophanes [10]. However, the use of sulfur atoms as binding units within cyclophane units is limited. The few examples include those compounds known to bind strongly to gold surfaces thus making it possible for several self-assembled monolayers of adsorbates with a surface-active sulfur group, an alkyl chain and a terminal functional group [11] [12]. Reinhoudt and his coworkers also reported the synthesis of various resorcin [4] arene adsorbates with four dialkyl sulfide chains underneath, a receptor, which they used in detecting a specific gas [13]-[17]. In this study sulfur units were employed to freeze the conformation of some cyclophanes in order to use them for metal ion recognition studies.

\section{Experimental}

All melting points are uncorrected. IR ( $\mathrm{KBr}$ or $\mathrm{NaCl})$ : Nippon Denshi JIR-AQ2OM. ${ }^{1} \mathrm{H}$ NMR: Nippon Denshi JEOL FT-270 in $\mathrm{CDCl}_{3}$, TMS as reference. UV: Hitachi 220A spectrophotometer. MS: Nippon Denshi JMS01SA-2. Elemental analysis: Yanaco MT-5.

\subsection{Direct Cyclization of 2,6-Bis(bromomethyl)-4-tert-butylanisole with Tos MIC [3] [18]}

To a suspension of $\mathrm{NaH}(2.1 \mathrm{~g}, 51 \mathrm{mmol})$ in DMF (35 ml) a solution of 2,6-bis(bromomethyl)-4-tert-butylanisole (6 g, $17.1 \mathrm{mmol}$ ) and TosMIC (3.3 g, $22.0 \mathrm{mmol})$ in DMF ( $35 \mathrm{ml}$ ) was added dropwise over a period of $6 \mathrm{~h}$. After the suspension was stirred for additional $5 \mathrm{~h}$ at room temperature, it was gently poured into ice-water (300 $\mathrm{ml})$ and extracted with $\mathrm{CH}_{2} \mathrm{Cl}_{2}(3 \times 100 \mathrm{ml})$ and washed with water $(200 \mathrm{ml})$, dried with $\mathrm{Na}_{2} \mathrm{SO}_{4}$, and concentrated in vacuo to $15 \mathrm{ml}$ after which conc $\mathrm{HCl}(15 \mathrm{ml})$ was added. The solution was stirred for $15 \mathrm{~min}$. The or-
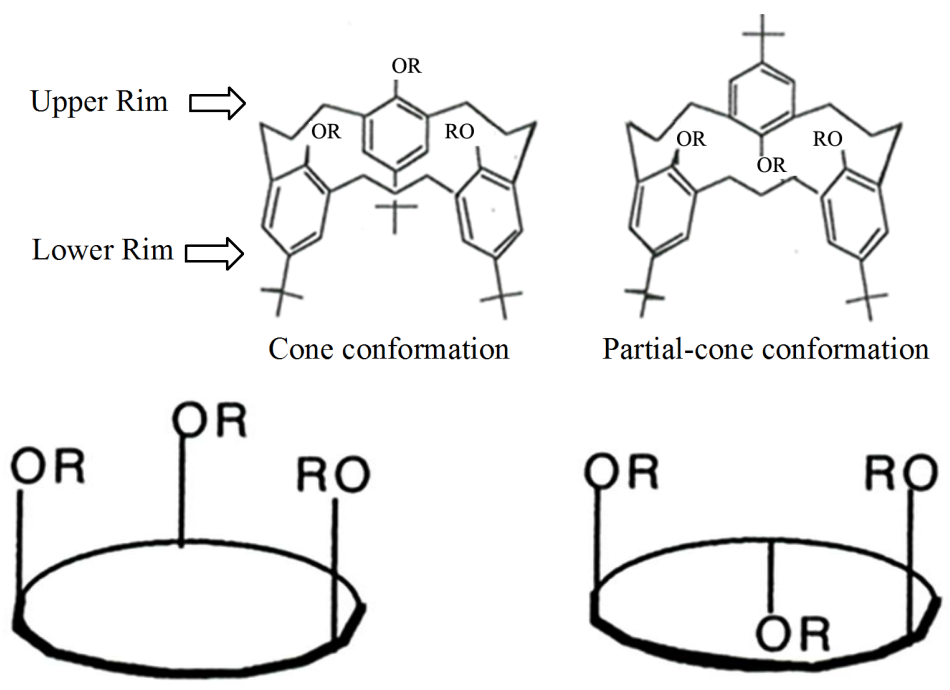

Figure 1. Possible conformers for [3.3.3]metacyclophanes [3]-[5]. 
ganic layer was again extracted with $\mathrm{CH}_{2} \mathrm{Cl}_{2}(3 \times 100 \mathrm{ml})$, washed with water $(2 \times 100 \mathrm{ml})$ dried with $\mathrm{Na}_{2} \mathrm{SO}_{4}$, and concentrated under reduced pressure. The residue was chromatographed on silica gel using benzene/ $\mathrm{CHCl}_{3}$ $(1: 1 \mathrm{v} / \mathrm{v})$ as eluting solvents to give $821.2 \mathrm{mg}(1.25 \mathrm{mmol}, 22 \%)$ of 6,15,24-tri-tert-butyl-9,18,27-trimethoxy [3.3.3]metacyclophane-2,11,20-trione (1); colorless prisms (benzene), m.p. $228^{\circ} \mathrm{C}-229^{\circ} \mathrm{C}$. IR $(\mathrm{KBr}): v\left[\mathrm{~cm}^{-1}\right]=$ $1720(\mathrm{C}=\mathrm{O}) .{ }^{1} \mathrm{H}$ NMR $\left(\mathrm{CDCl}_{3}\right): \delta=1.20(27 \mathrm{H}, \mathrm{s}), 3.34(9 \mathrm{H}, \mathrm{s}), 3.62(12 \mathrm{H}, \mathrm{s}), 6.92(6 \mathrm{H}, \mathrm{s}) . \mathrm{MS}(75 \mathrm{eV}): \mathrm{m} / \mathrm{z}=654$ $\left[\mathrm{M}^{+}\right] . \mathrm{C}_{42} \mathrm{H}_{54} \mathrm{O}_{6}$ (654.9): calcd. C 77.03, H 8.31; found, C 76.97, H 8.19.

\subsection{Preparation of 6,15,24-Tri-tert-butyl-9,18,27-trimethoxy[3.3.3] metacyclophane-2,11-dione 3}

To a suspension of $\mathrm{NaH}(2.1 \mathrm{~g}, 51 \mathrm{mmol})$ in DMF $(150 \mathrm{ml})$ a solution of 1,3-bis [5-tert-butyl-3-(bromomethyl)2-methoxyphenyl]propane (4.7 g, $8.5 \mathrm{mmol}$ ) and a TosMIC adduct (5.0 g, $8.5 \mathrm{mmol})$ in DMF (35 ml) was added dropwise over a period of $6 \mathrm{~h}$ after which the suspension was stirred for an additional $5 \mathrm{~h}$ at room temperature. It was gently poured into ice-water $(300 \mathrm{ml})$ and extracted with $\mathrm{CH}_{2} \mathrm{Cl}_{2}(3 \times 100 \mathrm{ml})$, washed with water $(2 \times 200$ $\mathrm{ml}$ ), dried with $\mathrm{Na}_{2} \mathrm{SO}_{4}$, and concentrated in vacuo to $15 \mathrm{ml}$. Conc. $\mathrm{HCl}(15 \mathrm{ml})$ was added, and the solution was stirred for $15 \mathrm{~min}$. The organic layer was again extracted with $\mathrm{CH}_{2} \mathrm{Cl}_{2}(3 \times 100 \mathrm{ml})$, washed with water $(2 \times 100$ $\mathrm{ml}$ ), dried with $\mathrm{Na}_{2} \mathrm{SO}_{4}$, and concentrated and condensed under reduced pressure. The residue was chromatographed on silica gel using $\mathrm{CHCl}_{3}$ as solvent to give crude $\mathbf{3}$ as a pale yellow solid. Recrystallization from benzene yielded $3.70 \mathrm{~g}$ (5.78 mol, 68\%) of 6,15,24-tri-tert-butyl-9,18,27-trimethoxy [3.3.3]metacyclo-phane-2,11dione 3 as pale yellow prisms, m. p. $188^{\circ} \mathrm{C}-189^{\circ} \mathrm{C}$. IR $(\mathrm{KBr}): v\left[\mathrm{~cm}^{-1}\right]=1716(\mathrm{C}=\mathrm{O}) .{ }^{1} \mathrm{H}$ NMR $\left(\mathrm{CDCl}_{3}\right): \delta=$ 1.19 (9 H, s), 1.27 (18 H, s), 1.79 - 1.85 (2 H, m), 2.51 - 2.60 (4 H, m), 3.07 (3 H, s), 3.38 (6 H, s), 3.58 (4 H, s), $3.60(4 \mathrm{H}, \mathrm{s}), 6.95(2 \mathrm{H}, \mathrm{s}), 7.06(4 \mathrm{H}, \mathrm{s}) . \mathrm{MS}(75 \mathrm{eV}): \mathrm{m} / \mathrm{z}=640\left[\mathrm{M}^{+}\right] . \mathrm{C}_{42} \mathrm{H}_{56} \mathrm{O}_{5}(640.9)$; calcd. C 78.71, H 8.81; found C 78.95, H 8.77.

\subsection{Synthesis of 2,11-Bis(ethanedithia)-9,18,27-trimethoxy-6,15,24-tri-tert-butyl[3.3.3] metacyclophane 2}

To a mixture of compound 3 (200 mg, $0.312 \mathrm{mmol})$ and acetic acid $(10 \mathrm{ml})$ was added 1,2-ethanedithiol ( $0.5 \mathrm{ml}$, $5.96 \mathrm{mmol})$ and boron trifluoride etherate $\left[\mathrm{BF}_{3} \cdot \mathrm{OEt}_{2}\right](0.1 \mathrm{ml}, 0.392 \mathrm{mmol})$, and the resulting reaction mixture stirred at room temperature for $24 \mathrm{~h}$. The reaction mixture was gently poured into ice-water $(50 \mathrm{ml})$ and extracted with $\mathrm{CHCl}_{3}(4 \times 50 \mathrm{ml})$. The $\mathrm{CHCl}_{3}$ layer was washed with $10 \% \mathrm{NaHCO}_{3}(2 \times 50 \mathrm{ml})$, and water $(2 \times 50$ $\mathrm{ml}$ ), dried with $\mathrm{Na}_{2} \mathrm{SO}_{4}$ and then evaporated under reduced pressure leaving a residue which was chromatographed over silica gel (C-300 Wako gel, $100 \mathrm{~g}$ ) with $\mathrm{CHCl}_{3}$ as solvent. This gave a solid crude which was recrystallized from methanol to obtain $200 \mathrm{mg}(81 \%)$ of the cyclic thioketal as white crystals with melting point as $168^{\circ} \mathrm{C}-169^{\circ} \mathrm{C}$. IR $\left.(\mathrm{KBr}): v \mathrm{~cm}^{-1}\right]=2955,2925,2866,2824,1503,1500,1481,1453,1392,1352,1331,1295$, 1276, 1244, 1202, 1174, 1115, 1016, 968, 825, 809. ${ }^{1} \mathrm{H}$ NMR: $\delta=1.30(18 \mathrm{H}, \mathrm{s}), 1.34$ (9H, s), 1.27 - $1.34(4 \mathrm{H}$, m), 1.86 - 2.00 (2H, m), 2.64 (6H, s, broad), 3.14 (3H, s, broad), 3.30-3.37 (16H, m), 7.06 (2H, d, J = $2.44 \mathrm{~Hz})$, $7.56(2 \mathrm{H}, \mathrm{d}, \mathrm{J}=2.44 \mathrm{~Hz}), 7.76(2 \mathrm{H}, \mathrm{s})$. MS $(75 \mathrm{eV}): \mathrm{m} / \mathrm{z}=793\left[\mathrm{M}^{+}\right] . \mathrm{C}_{46} \mathrm{H}_{64} \mathrm{O}_{3} \mathrm{~S}_{4}$ (793.28); calcd. C 69.25, $\mathrm{H}$ 8.13; found C 69.81, H 8.11.

\subsection{Synthesis of 2,11,20-Tris(ethanedithia)-9,18,27-trimethoxy-6,15,24-tri-tert-butyl [3.3.3] metacyclophane 2}

The synthesis and purification is the same as indicated above, yielding $191 \mathrm{mg}(70 \%)$ of this cyclic thioketal, a white crystal after recrystallization from hexane, m. p. $254^{\circ} \mathrm{C}-255^{\circ} \mathrm{C}$. IR $(\mathrm{KBr}): v\left[\mathrm{~cm}^{-1}\right]=2960,2923,2867$, 2822, 1684, 1652, 1634, 1603, 1540, 1481, 1463, 1429, 1392, 1361, 1333, 1296, 1276, 1246, 1203, 1174, 1118, 1016, 956, 883. ${ }^{1} \mathrm{H}$ NMR $\left(\mathrm{CDCl}_{3}\right): \delta=1.29$ (18H, s), 1.34 (9H, s), 2.72 (3H, s, broad), 2.98 (6H, s, broad), 3.21 (8H, d, J = $14.16 \mathrm{~Hz}), 3.19$ - $3.24(4 \mathrm{H}, \mathrm{m}), 3.38$ (8H, s, broad), $3.50(4 \mathrm{H}, \mathrm{d}, \mathrm{J}=14.16 \mathrm{~Hz}), 7.59$ (2H, d, J = 1.95 $\mathrm{Hz}$ ), 7.70 (2H, d, J = $1.95 \mathrm{~Hz}), 7.74\left(2 \mathrm{H}, \mathrm{s}\right.$, broad). $\mathrm{MS}(75 \mathrm{eV}): \mathrm{m} / \mathrm{z}=883\left[\mathrm{M}^{+}\right] . \mathrm{C}_{46} \mathrm{H}_{64} \mathrm{O}_{3} \mathrm{~S}_{6}$ (883.44); calcd. C 65.26, H 7.53; found C 64.87, H 7.17.

\subsection{Determination of the Number of Silver Ions Complexed to 2,11,20-Tris(ethanedithia)- 9,18,27-trimethoxy-6,15,24-tri-tert-butyl[3.3.3]metacyclophane 2 Using the Mole Ratio Method [19]}

A freshly prepared stock solution of the host, cyclic thioketal $2\left[40 \times 10^{-5} \mathrm{M}\right]$ using THF (UV grade) was se- 
rially diluted to obtain $10 \mathrm{ml}$ each of various concentrations. $5 \mathrm{ml}$ of each of these solutions was mixed with 5 $\mathrm{ml}$ of $5.0 \times 10^{-5} \mathrm{M}$ solution of silver picrate (also in THF). These mixtures were shaken at $26^{\circ} \mathrm{C}$ for $3 \mathrm{~h}$ after which the absorbance of each was measured on a UV spectrophotometer in the wavelength range $500-200 \mathrm{~nm}$. Absorbances at $220 \mathrm{~nm}$ were plotted against the mole ratio of host to guest which were whole numbers of $1,2,3$, 4,5 , and 6 . The point of inflexion on the mole ratio axis (x-axis) gave the number of silver ions complexed as 3 .

\section{Results and Discussion}

The starting materials 6,15,24-tri-tert-butyl-9,18,27-trimethoxy [3.3.3]metacyclophane-2,11,20-trione (1) and 6,15,24-tri-tert-butyl-9,18,27-trimethoxy[3.3.3]metacyclophane-2,11-dione (3) were readily available via wellestablished procedures [3] [17] [18] [20] [21] in 22\% and 68\% yields respectively. Their spectral properties [22]-[27] also compared very well with those of literature [4] [5] [28]-[34].

In attempt to convert the flexible [3.3.3]metacyclophane-2,11,20-trione $\mathbf{1}$ and -2,11-dione $\mathbf{3}$ into rigid host compounds to be used for complexation studies, sulfurization reactions were carried out on them. Thus ketones $\mathbf{1}$ and 3 were converted into cyclic thioketals $\mathbf{2}$ and $\mathbf{4}$ (Scheme 1). From dynamic ${ }^{1} \mathrm{H}$ NMR studies, the cyclic thioketal 2 which was found to be slightly flexible in solution at $27^{\circ} \mathrm{C}$ was fixed in a " partial-cone " conformation below $-10^{\circ} \mathrm{C}$ by the observation of two pairs of doublets for the benzylic protons (relative intensity 2:1) in the ${ }^{1} \mathrm{H}$ NMR spectrum, Figure 2. Besides other changes in both the aromatic and aliphatic regions of the proton ${ }^{1} \mathrm{H}$ NMR spectra Figure 2, the aromatic protons gave two slightly broad singlets in the region $\delta 7.0-7.6 \mathrm{ppm}$ below $0^{\circ} \mathrm{C}$.

This could be interpreted to mean the inversion of one of the benzene rings, precisely the signal up-field. A further confirmation of this arrangement of the benzene rings could also be deduced from the intensities of the two sets of aromatic signals. The two broad signals have been integrated and show 4 protons at $7.6 \mathrm{ppm}$ and 2 protons at $7.2 \mathrm{ppm}$ which can be interpreted as one of the three benzene rings undergoing inversion.

The coalescence temperature (Tc) for the benzylic protons was found to be $0^{\circ} \mathrm{C}$ and the free energy of activation for the ring inversion was estimated to be $13.2 \mathrm{kcal} / \mathrm{mol}$. The rate of inversion at the coalescence temperature was calculated from the expression; Kcoalescence $=\pi\left(\Delta v^{2}+6 \mathrm{~J}^{2}\right)^{1 / 2} / 2^{1 / 2}$ where $\Delta v$ is the difference in chemical shift between the centres of the two doublets arising from the benzylic protons, and $\mathrm{J}$ is the coupling constant. Substituting this value into the Eyring rate equation ${ }^{35}$ gives the expression; $\Delta \mathrm{G}^{\neq}=\mathrm{RT} \ln \left(6.62 \times 10^{12}\right.$ / Kcoalescence) which was used for the estimation of the free energy of activation for ring inversion.

Titration of the cyclic thioketal 2 with $\mathrm{CF}_{3} \mathrm{SO}_{3} \mathrm{Ag}$ in acetone- $\mathrm{d}_{6} / \mathrm{CDCl}_{3}(3: 1 \mathrm{v} / \mathrm{v})$, monitored by ${ }^{1} \mathrm{H} \mathrm{NMR}$, Figure 3, clearly demonstrates that a 1:3 complex with "partial-cone" conformation is formed which is quite stable on the NMR time scale.

This ratio of complexation for the cyclic thioketal 2 with $\mathrm{Ag}^{+}$was experimentally confirmed by the mole ratio method, Figure 4. A two-phase solvent extraction experiment indicated that the cyclic thioketal 2 shows a strong affinity for the $\mathrm{Ag}^{+}$making it possible for a high $\mathrm{Ag}^{+}$selectivity to be observed, Figure 5 . The lone pairs of electrons on the sulfur atoms and the $\pi$-electrons of the benzene rings might be responsible for the binding of the silver ions. Thus these two groups arrange themselves in a manner forming pockets into which the silver ions enter, Figure 6.

On the contrary, the parent triketone $\mathbf{1}$ shows a rather poor metal affinity, Figure 5. Shinkai and his coworkers have reported the intramolecular tunneling of $\mathrm{Ag}^{+}$through the cavity of 1,3-alternate conformer of calix

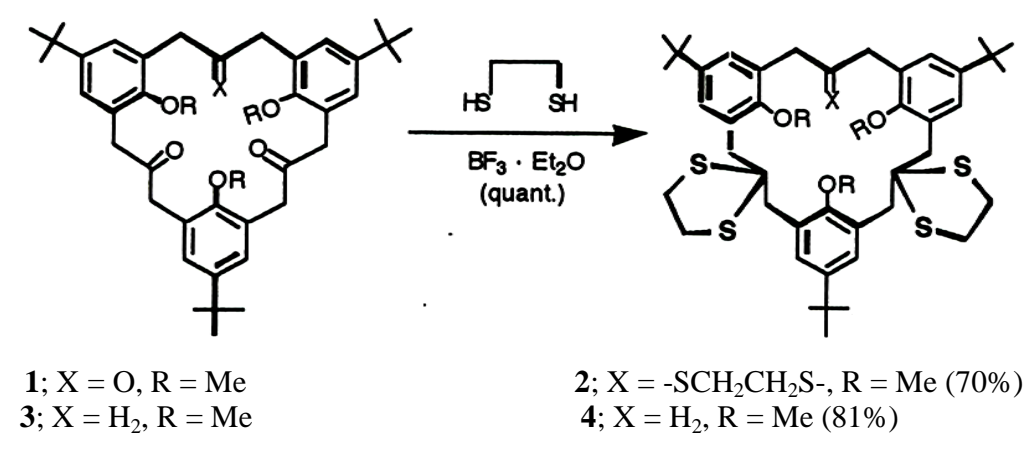

Scheme 1. Synthesis of [3.3.3]metacyclophane cyclic thioketals 2 and $\mathbf{4}$. 


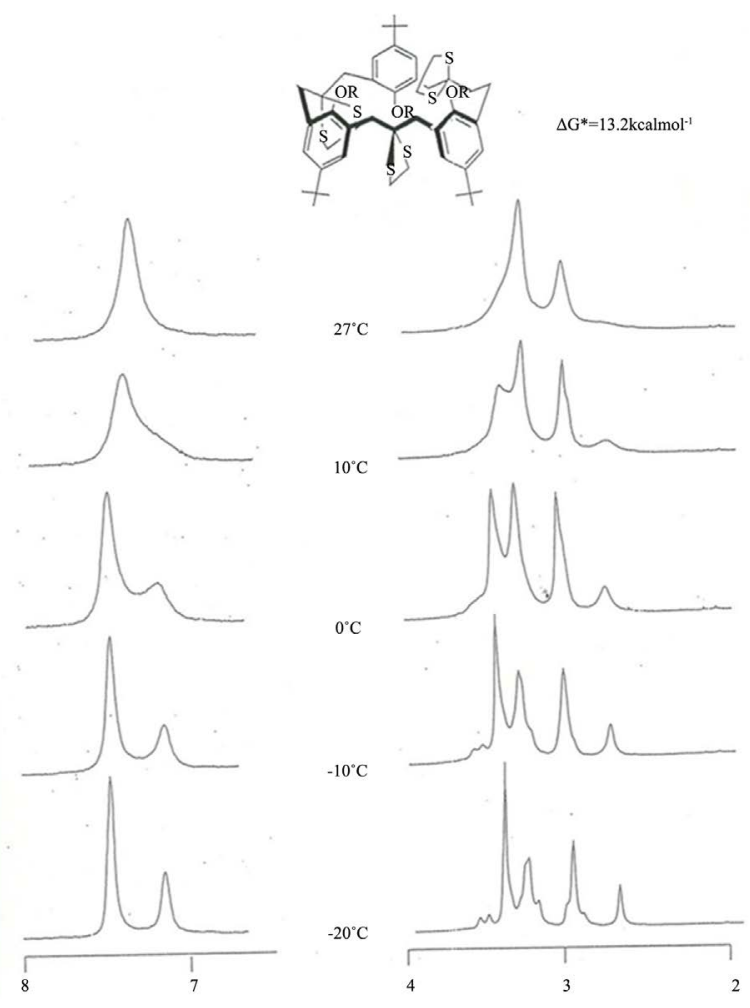

Figure 2. Partial variable temperature ${ }^{1} \mathrm{H}$ NMR spectra of 2 in $\mathrm{CS}_{2} / \mathrm{CDCl}_{3}$ [3:1 v/v] at $270 \mathrm{MHz}, \delta(\mathrm{ppm})[4][5]$.

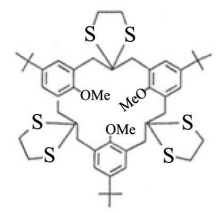

Ratio of Host to Guest

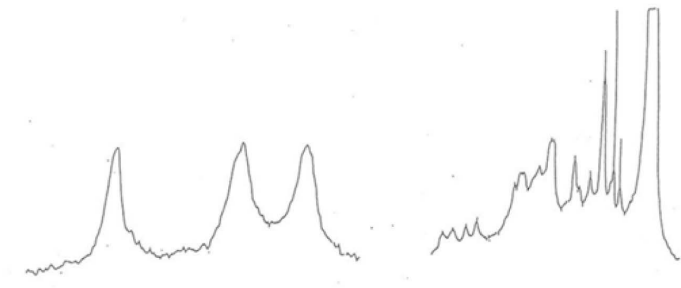

$1: 3$
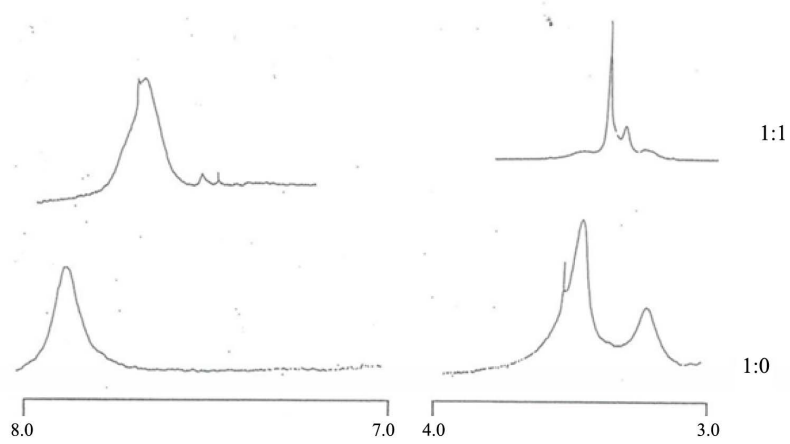

Figure 3. Partial ${ }^{1} \mathrm{NMR}$ spectra of the titration of $\mathbf{2}$ in Acetone- $\mathrm{D}_{6} / \mathrm{CDCl}_{3}[3: 1$ v/v] against $\mathrm{Ag}^{+}$at $270 \mathrm{MHz}, \delta(\mathrm{ppm}), 27^{\circ} \mathrm{C}$. 


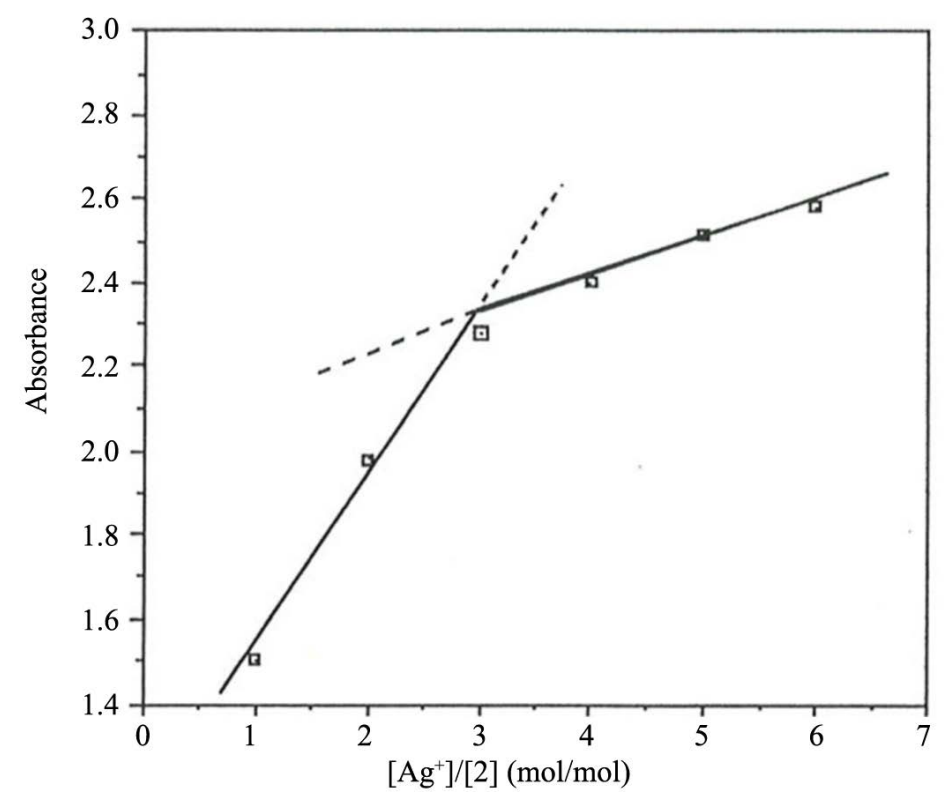

Figure 4. Complexation involving host 2 and silver picrate (mole ratio method).
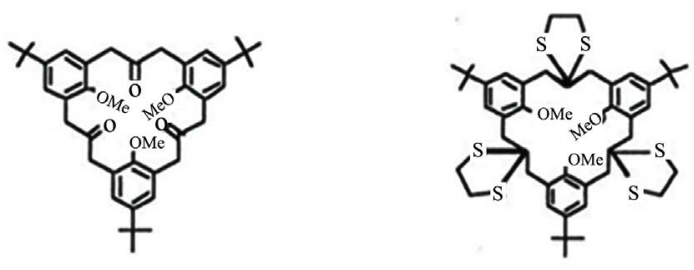

Extractability (Ex \%):

0

82

Figure 5. Extraction of silver ions with [3.3.3]metacyclophane derivatives.
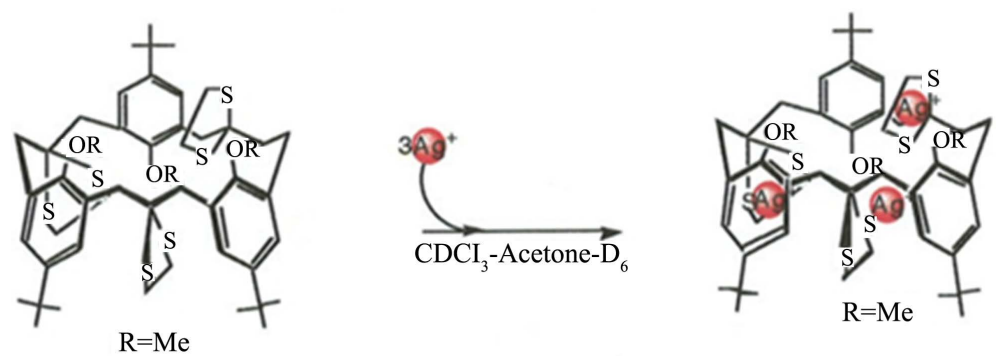

Figure 6. Silver ions filling pockets in compound 2.

[4] arene, a motion that they named "Metal Tunnelling" [36].

Extraction conditions: Aqueous phase $(5 \mathrm{ml})$ contains $\mathrm{AgNO}_{3}$ [Guest] $\left(2.5 \times 10^{-4} \mathrm{M}\right)$ for $\mathrm{Ag}^{+}$. Organic phase $\left(\mathrm{CH}_{2} \mathrm{Cl}_{2}, 5 \mathrm{ml}\right)$ contains [3.3.3]metacyclophane derivative (Host) $\left(2.5 \times 10^{-4} \mathrm{M}\right)$. Extractabilities were determined by U. V. spectroscopy.

Interestingly, an intramolecular $\mathrm{Ag}^{+}$rolling phenomenon in which the $\mathrm{Ag}^{+}$rolls from one binding site to the other in a circular motion like a "Molecular Roulette" was observed for the first time by ${ }^{1} \mathrm{H}$ NMR spectroscopy in the 1:1 complex between the cyclic thioketal 2 and $\mathrm{Ag}^{+}$above room temperature, Figure 7 and Figure 8. A mole ratio of 1:1 of the cyclic thioketal 2 and $\mathrm{Ag}^{+}$seems to portray a picture in which the $\mathrm{Ag}^{+}$undergoes an in- 

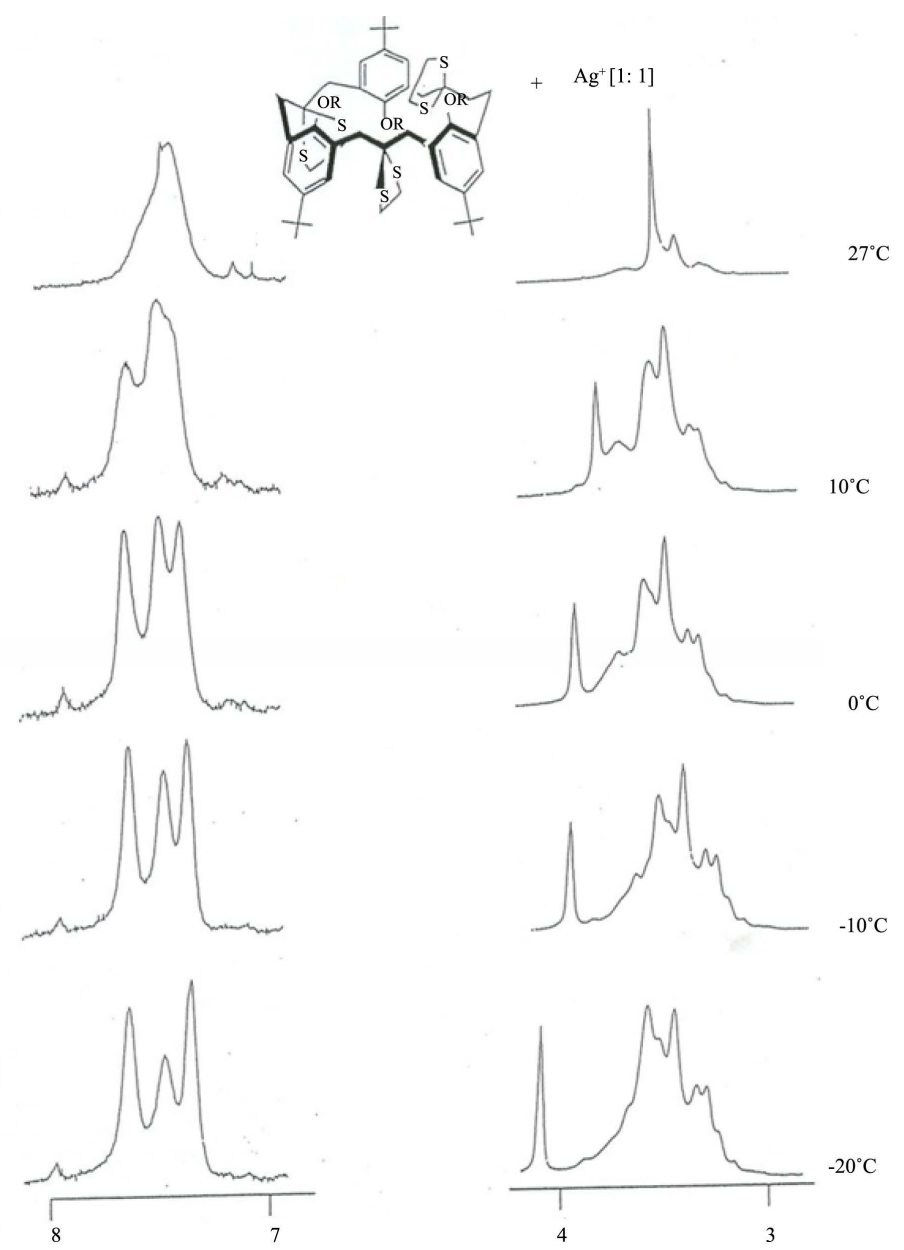

Figure 7. Partial variable temperature ${ }^{1} \mathrm{H}$ NMR spectra of the titration of $\mathbf{2}+$ $\mathrm{CF}_{3} \mathrm{SO}_{3} \mathrm{Ag}[1: 1 \mathrm{~mol} / \mathrm{mol}]$ in acetone- $\mathrm{D}_{6} / \mathrm{CDCl}_{3}[3: 1 \mathrm{v} / \mathrm{v}]$ at $270 \mathrm{MHz}, \delta(\mathrm{ppm})$ [4] [5].

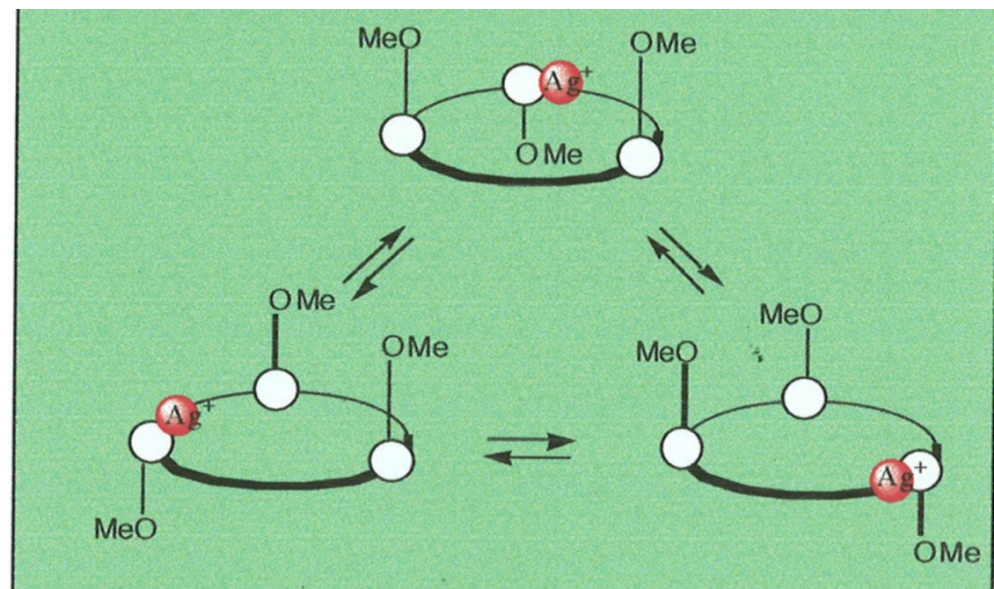

Figure 8. Intramolecular $\mathrm{Ag}^{+}$rolling phenomenon like a "Molecular Roulette".

termolecular motion between the uncomplexed cyclic thioketal 2 and the complexed, Figure 9. One cannot rule out the possibility of the intramolecular motion, like that of the "Molecular Roulette", also occurring in this sys- 

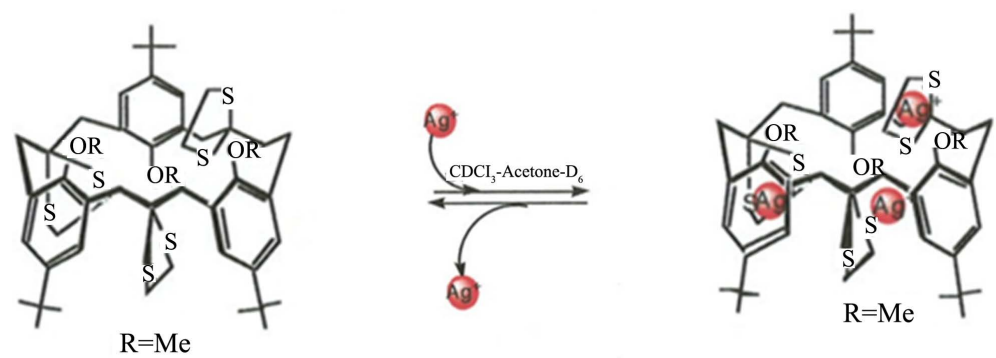

Figure 9. The inter- and intramolecular motion between uncomplexed and complexed cyclic thioketal 2.

tem. Similar studies involving the cyclic thioketal $\mathbf{4}$ are currently going on.

\section{Conclusion}

We have synthesized 2,11,20-tris(ethanedithia)-9,18,27-trimethoxy-6,15,24-tri-tert-butyl[3.3.3]metacyclophane 2 and 2,11-bis(ethanedithia)-9,18,27-trimethoxy-6,15,24-tri-tert-butyl[3.3.3]metacyclophane 4 in yields of 70\% and $81 \%$ respectively. Solution Proton Nuclear Magnetic Resonance ( ${ }^{1} \mathrm{H}$ NMR) studies revealed the conformations of $\mathbf{2}$ and $\mathbf{4}$ to be partial-cone. The affinity of compound $\mathbf{2}$ for silver ions was found to be $82 \%$ high. The multi-membered carbon skeleton of the [3.3.3]metacyclophane system was very stable as it allowed the introduction of the thio functional groups into the carbonyl units without ring-opening side reactions. The studies so far have shown an Intramolecular Motion by the silver ions within compound $\mathbf{2}$ that we have named "Molecular Roulette”, the first of its kind within the [3.3.3]metacyclophanes and their derivatives.

\section{References}

[1] Cram, D.J. (1983) Cyclophanes, Vol. 1. Keehn, P.M. and Rosenfeld, S.N., Eds., Academic Press, New York, 1-21.

[2] Doamekpor, L.K., Nartey, V.K., Klake, R.K. and Yamato, T. (2012) Synthesis and Conformational Studies of some Metacyclophane Compounds. International Journal of Organic Chemistry, 2, 152-158. http://dx.doi.org/10.4236/ijoc.2012.22023

[3] Yamato, T., Doamekpor, L.K., Koizumi, K., Kishi, K., Haraguchi, M. and Tashiro, M. (1995) Synthesis and Conformational Studies of Calixarene-Analogous Trihydroxy[3.3.3]metacyclophanes and Their O-Alkylated Derivatives. Liebigs Annalen, 7, 1259-1267. http://dx.doi.org/10.1002/jlac.1995199507167

[4] Doamekpor, L.K. (1996) Synthesis, Conformation and Molecular Recognition Studies on Calixarene-Analogous[3.n.n] Metacyclophanes. Ph.D. Thesis, Saga University, Saga.

[5] Yamato, T., Kohno, K. and Tsuchihashi, K. (2002) Synthesis, Structures and Ion Selectivity of Homocalix[3]arene Thioketals Derived from Homocalix[3]arene Ketones. Journal of Inclusion Phenomena and Macrocyclic Chemistry, 43, 137-144. http://dx.doi.org/10.1023/A:1020447613192

[6] Odashima, K. and Koga, K. (1983) Cyclophanes, Vol. 2. Keehn, P.M. and Rosenfeld, S.N., Eds., Academic Press, New York, 629-677.

[7] Tabushi, I. and Yamamura, K. (1983) Water-Soluble Cyclophanes as Hosts and Catalysts. Topics in Current Chemistry. 113, 145-182. http://dx.doi.org/10.1007/3-540-12397-0 3

[8] Diederich, F. (1988) Complexation of Neutral Molecules by Cyclophane Hosts. Angewandte Chemie, 100, $372-396$. http://dx.doi.org/10.1002/ange.19881000307

[9] Diederich, F. (1991) Monographs in Supramolecular Chemistry. Stoddart, J.F., Ed., The Royal Society of Chemistry, Cambridge, 1-51.

[10] Albert, B., Jansen, M., Güther, R. and Vögtle, F. (1993) 2,11-Dithia[3.3]metacyclophane-9-carboxylic Acid Tert-Butyl Ester. Acta Crystallographica, C49, 2002-2003. http://dx.doi.org/10.1107/S0108270193004561

[11] Morisaki, Y., Ishida, T. and Chujo, Y. (2006) Oxidation of Dithia[3.3]Metacyclophane-Containing Through-Space $\pi$ Conjugated Polymer. Polymer Bulletin, 57, 623-630. http://dx.doi.org/10.1007/s00289-006-0622-3

[12] Sánchez, M., Höpfl, H., Ochoa, M.E., Farfán, N., Santillan, R. and Rojas-Lima, S. (2002) Facile Preparation of [4.4]Metacyclophane- and [5.5]Paracyclophane-Type Macrocycles from Arylboronic Acids and Salicylideneaminoaryl Alcohols. Chemistry-A European Journal, 8, 612-621. 
http://dx.doi.org/10.1002/1521-3765(20020201)8:3<612::AID-CHEM612>3.0.CO;2-4

[13] Bain, C.D., Troughton, E.B., Tao, Y.-T., Evall, J., Whitesides, G.M. and Nuzzo, R.G. (1989) Formation of Monolayer Films by Spontaneous Assembly of Organic Thiols from Solution onto Gold. Journal of the American Chemical Society, 111, 321-335. http://dx.doi.org/10.1021/ja00183a049

[14] Laibinis, P.E., Whitesides, G.M., Allara, D.L., Tao, Y.-T., Parikh, A.N. and Nuzzo, R.G. (1991) Comparison of the Structures and Wetting Properties of Self-Assembled Monolayers of N-Alkanethiols on the Coinage Metal Surfaces, Cu, Ag, Au. Journal of the American Chemical Society, 113, 7152-7167. http://dx.doi.org/10.1021/ja00019a011

[15] van Velzen, E.U.T., Engbersen, J.F.J. and Reinhoudt, D.N. (1995) Synthesis of Self-Assembling Resorcin[4]Arene Tetrasulfide Adsorbates. Synthesis, 1995, 989-997. http://dx.doi.org/10.1055/s-1995-4021

[16] van Velzen, E.U.T., Engbersen, J.F.J. and Reinhoudt, D.N. (1994) Self-Assembled Monolayers of Receptor Adsorbates on Gold-Preparation and Characterization. Journal of the American Chemical Society, 116, 3597-3598. http://dx.doi.org/10.1021/ja00087a055

[17] Weiss, T., van Velzen, E.U.T., Engbersen, J.F.J., Reinhoudt, D.N. and Göpel, W. (1994) Molecular Recognition by Self-Assembled Monolayers of Cavitand Receptors. Science, 265, 1413-1415.

[18] Breitenbach, J. and Vögtle, F. (1992) Macrocyclizations with TosMIC-Yielding [3 $\mathrm{n}$ ]Metacyclophanes. Synthesis, 1992, 41-43. http://dx.doi.org/10.1055/s-1992-34171

[19] (1991) Kikibunseki nyumon Nihonbunseki Kagaku Kai Kyushu Shibuhen. Fukuoka, Kyushu, 22.

[20] Breitenbach, J., Ott, F. and Vögtle, F. (1992) Selective Ketone Pyrolysis: New Synthetic Method for Mono- and Polycyclic Hydrocarbons. Angewandte Chemie International Edition in English, 31, 307-308. http://dx.doi.org/10.1002/anie.199203071

[21] Ott, F., Breitenbach, J., Nieger, M. and Vögtle, F. (1993) Selective Ketone Pyrolysis-New Examples. Chemische Berichte, 126, 97-101. http://dx.doi.org/10.1002/cber.19931260116

[22] Smith, B.H. (1964) Bridged Aromatic Compounds. Academic Press, New York.

[23] Vögtle, F. and Neumann, P. (1972) Stereochemistry of [2.2]Metacyclophanes. Angewandte Chemie International Edition in English, 11, 73-83. http://dx.doi.org/10.1002/anie.197200731

[24] Vgtle, F. and Neumann, P. (1973) The Synthesis of [2.2]Phanes. Synthesis, 1973, 85-103. http://dx.doi.org/10.1055/s-1973-22137

[25] Vögtle, F. and Höhner, G. (1978) Stereochemistry of Multibridged, Multilayered, and Multistepped Aromatic Compounds-Transanular Steric and Electronic Effects. Topics in Current Chemistry, 74, 1-29. http://dx.doi.org/10.1007/bfb0050144

[26] Keehn, P.M. and Rosenfeld, S.N. (1983) Cyclophanes. Academic Press, New York.

[27] Vögtle, F. (1993) Cyclophane Chemistry. John Wiley \& Sons Ltd., Hoboken.

[28] Tashiro, M. and Yamato, T. (1981) Selective Preparation. 30. A Convenient Preparation of 5,13-Di-tert-butyl-8,16disubstituted-[2.2]metacyclophanes and Their Trans-tert-Butylation and Halogenation. The Journal of Organic Chemistry, 46, 1543-1552. http://dx.doi.org/10.1021/jo00321a005

[29] Tashiro, M. and Yamato, T. (1981) Metacyclophanes and Related Compounds. 1. Preparation and Nuclear Magnetic Resonance Spectra of 8,16-Disubstituted[2.2]metacyclophanes. The Journal of Organic Chemistry, 46, 4556-4562. http://dx.doi.org/10.1021/jo00335a047

[30] Tashiro, M. and Yamato, T. (1983) Metacyclophanes and Related Compounds. 8. Preparation and Reactions of 8, 16Diformyl[2.2]metacyclophanes. The Journal of Organic Chemistry, 48, 1461-1468. http://dx.doi.org/10.1021/jo00157a015

[31] Tashiro, M. and Yamato, T. (1985) Metacyclophanes and Related Compounds. 14. Preparation of 8,16-Difluoro[2.2]metacyclophane. The Journal of Organic Chemistry, 50, 2939-2942. http://dx.doi.org/10.1021/jo00216a026

[32] Yamato, T., Matsumoto, J., Tokuhisa, K., Tsuji, K., Suehiro, K. and Tashiro, M. (1992) Medium-Sized Cyclophanes. Part 18. 5-tert-Butyl-8-substituted[2.2]metaparacyclophanes: Preparation, X-Ray Diffraction Studies, and Their Treatment with Lewis Acids. Journal of the Chemical Society, Perkin Transactions, 1, 2675-2682. http://dx.doi.org/10.1039/p19920002675

[33] Yamato, T., Miyazawa, A. and Tashiro, M. (1993) Medium-Sized Cyclophanes. Part 31. Synthesis and Electrophilic Substitution of 8-Substituted[2]metacyclo[2](1,3)pyrenophanes. Journal of the Chemical Society, Perkin Transactions, 1, 3127-3137. http://dx.doi.org/10.1039/p19930003127

[34] Yamato, T., Miyazawa, A. and Tashiro, M. (1993) Medium-Sized Cyclophanes, 29. Synthesis and Desulfurization of 2,11-Dithia[3]metacyclo- and 2,11-Dithia[3]paracyclo[3](4,9)pyrenophanes. Chemische Berichte, 126, 2505-2511. http://dx.doi.org/10.1002/cber.19931261126 
[35] Kurland, R.S., Rubin, N.B. and Wise, W.B.J. (1964) Inversion Barrier in Singly Bridged Biphenyls. The Journal of Chemical Physics, 40, 2426. http://dx.doi.org/10.1063/1.1725541

[36] Takeshita, M. and Shinkai, S. (1995) Recent Topics on Functionalization and Recognition Ability of Calixarenes: The “Third Host Molecule”. Bulletin of the Chemical Society of Japan, 68, 1088-1097.

http://dx.doi.org/10.1246/bcsj.68.1088 